\title{
STRATEGI GURU DALAM MEMBINA PERKEMBANGAN EMOSI ANAK USIA 5-6 TAHUN MELALUI DIALEK YANG BAIK DI TK NEGERI PEMBINA KECAMATAN BELO
}

\author{
Aqidah \\ TK Negeri Pembina Kecamatan Belo \\ Email: aqidahhusen@gmail.com
}

\begin{abstract}
Abstrak
Anak usia dini sangat tertarik pada rekan-rekannya. Dengan menetapkan hubungan produktif, sosial positif dan hubungan kerja dengan anak-anak lain yang sebaya memberikan pondasi bagi pengembangan rasa kompetensi sosial. Seiring dengan proses perkembangan dan pertumbuhan, maka anak akan mengalami berbagai perubahan dalam hidupnya. Anak perlu memiliki kecerdasan sosial emosi yang baik dalam menghadapi kehidupan bermasyarakat dan sosialnya. Berdasarkan masalah tersebut maka penulis tertarik untuk meneliti Strategi Guru Dalam Membina Perkembangan Emosi Anak Usia 5-6 Tahun Melalui Dialek yang Baik di Tk Negeri Pembina Kecamatan Belo. Metodologi yang digunakan adalah metode kualitatif. Lokasi penelitian pendidikan anak usia dini adalah di Tk Negeri Pembina kecamatan Belo. Pengumpulan data menggunakan teknik wawancara, observasi, dan dokumentasi pada kepala sekolah, guru-guru yang ada di sekolah. Tekhnik Analisa Data terdiri atas Tekhnik Induktif, Tekhnik Analisa Deduktif, serta penarikan kesimpulan dan saran-saran. Berdasarkan hasil penelitian diperoleh kesimpulan bahwa strategi guru dalam membina perkembangan emosi anak usia 5-6 tahun melalui dialek yang baik di TK Negeri Pembina Kecamatan Belo adalah (a) Melakukan pendekatan secara emosional dengan anak. (b) Menyediakan lingkungan bermain dan permainan bagi anak. (c) Keteladanan dan pembiasaan. (d) Menerapkan peraturan dan tata tertib di sekolah. (e) Perlunya komunikasi antara orangtua dan guru.

Kata Kunci : Strategi Guru, Perkembangan Emosi, Dialek
\end{abstract}

\section{PENDAHULUAN}

Pendidikan anak usia 5-6 tahun adalah merupakan upaya pembinaan yang ditujukan kepada anak sejak lahir sampai dengan usia enam tahun yang dilakukan melalui pemberian stimulus pendidikan agar membantu perkembangan dan pertumbuhan baik jasmani maupun rohani sehingga anak memiliki kesiapan memasuki pendidikan lebih lanjut (Martinis Yamin, dkk, 2013). 
Manusia tidak akan pernah lepas dengan bahasa. Bahasa adalah sebuah konstruksi tanpa objek tetapi sangat melekat pada diri seorang pemakai bahasa. Dalam sebuah proses komunikasi secara primer seseorang kepada orang lain menggunakan simbol atau lambang bunyi/tulisan sebagai media. Lambang sebuah komunikasi adalah bahasa, isyarat, gambar, warna, dan sebagainya. Dalam bahasa menyimpan sebuah gagasan, ide, pokok pikiran yang akan disampaikan antara komunikator dan komunikan (George S. Morrison, 2012). Weijnen dkk dalam wahya, berpendapat bahwa dialek adalah sistem kebahasaan yang dipergunakan oleh satu masyarakat untuk membedakannya dari masyarakat lain yang bertetangga yang mempergunakan sistem yang berlainan walaupun erat hubungannya (Wahya, 2010).

Anak 5-6 tahun sangat tertarik pada rekan-rekannya. Dengan menetapkan hubungan produktif, sosial positif dan hubungan kerja dengan anak-anak lain yang sebaya memberikan pondasi bagi pengembangan rasa kompetensi sosial. Proses sosial emosi melibatkan perubahan dalam hubungan seseorang dengan orang lain, perubahan emosi, dan perubahan dalam kepribadian. Senyum seorang anak karena sentuhan ibu, serangan anak laki-laki pada teman bermainnya, semua itu mencerminkan perkembangan sosial emosi. Karena emosi memainkan peran yang sedemikian penting dalam kehidupan, maka penting diketahui bagaimana perkembangan dan pengaruh emosi terhadap penyesuaian pribadi dan social (George S. Morrison, 2012).

Seiring dengan proses perkembangan dan pertumbuhan Anak akan mengalami berbagai perubahan dalam hidupnya, seorang anak akan bertemu dan berkomunikasi dengan kelompok yang lebih besar dan luas lagi dan anak tidak hanya menghabiskan masa-masa dengan orangtua dan keluarga dekat dilingkungannya saja. Anak perlu memilki kecerdasan sosial emosi yang baik dalam menghadapi kehidupan bermasyarakat dan sosialnya.

Berkaitan dengan hal tersebut, penulis berupaya untuk melakukan penelitian pendahuluan untuk mengetahui keadaan yang sesungguhnya di lapangan dengan memilih TK Negeri Pembina Kecamatan Belo 
sebagai objek penelitian. Sehingga hal inilah yang membuat peneliti ingin meneliti tentang "Strategi Guru Dalam Membina Perkembangan Emosi Anak Usia 5-6 Tahun Melalui Dialek Yang Baik Di TK Negeri Pembina Kecamatan Belo".

\section{TINJAUAN TEORITIS}

\section{Strategi Guru Dalam Pembelajaran}

Guru adalah suatu profesi (M.Sobry Sutikno, 2013). Guru adalah tenaga pendidik yang memberikan sejumlah ilmu pengetahuan kepada anak didik di sekolah (Pupuh Fathurrohman \& M. Sobry Sutikno, 2010). Dalam Undang-undang Nomor 14 Tahun 2005 tentang guru dan dosen Bab 1 pasal 1 ayat (1) mendefinisikan bahwa guru adalah pendidik profesional dengan tugas utama mendidik, mengajar, membimbing, mengarahkan, melatih, menilai dan mengevaluasi peserta didik pada pendidikan anak usia dini jalur pendidikan formal, pendidikan dasar dan pendidikan menengah (Taman Firdaus, 2012).

Dengan demikian dapat dikatakan bahwa guru adalah adalah pendidik profesional dalam bidangnya dengan tugas utama mendidik, mengajar, membimbing, mengarahkan, melatih, menilai dan mengevaluasi peserta didik yang memiliki kecakapan pengetahuan akademis, juga kecakapan sosial, dan spritual, sehingga bisa membawa murid kearah perkembangan yang benar.

Strategi menurut istilah berasal dari kata benda dan kata kerja, yaitu strategos merupakan gabungan dari kata stratos :militer, dengan ego: memimpin. Sebagai kata kerja stratego berarti merencanakan (to plan) Dan secara bahasa diartikan sebagai cara, trik, dan kiat. Sedangkan pembelajaran menurut istilah adalah upaya untuk membelajarkan seseorang atau kelompok orang melalui berbagai upaya dan berbagai strategi, metode dan pendekataan kearah yang tujuanya sudah direncanakan (Abdul Majid, 2013). Strategi pembelajaran adalah caracara yang akan digunakan oleh pengajar untuk memilih kegiatan belajar yang akan digunakan selama proses pembelajaran. Pemilihan tersebut dilakukan dengan mempertimbangkan situasi dan kondisi, sumber belajar, kebutuhan dan karakteristik peserta didik yang dihadapi dalam mencapai tujuan pembelajaran tertentu (Puput Fathurrohman, 2011). 
Menurut Ridwan Abdullah Sani, strategi pembelajaran merupakan rencana tindakan termasuk penggunaan metode dan pemanfaatan berbagai sumber daya dalam pembelajaran. Strategi pembelajaran menentukan pendekatan yang dipilih oleh guru untuk mencapai pembelajaran. Hal tersebut selaras dengan penjelasan Wina Sanjaya bahwa strategi pembelajaran dapat diartikan sebagai perencanaan tentang rangkaian kegiatan yang didesain untuk mencapai tujuan pendidikan tertentu (Wina Sanjaya, 2013).

Dengan demikian, strategi guru merupakan rencana tindakan (rangkaian tindakan) termasuk penggunaan metode, dan pemanfaatan berbagai sumber daya dan kekuatan yang dimiliki dalam rangka membina dan mendidik anak sampai pada tingkat pengembangan kecerdasan yang dimiliki. Selain itu, strategi disusun untuk mencapai tertentu. Artinya, arah dari semua keputusan penyusunan strategi adalah pencapaian tujuan.

\section{Perkembangan Emosi Anak Usia 5-6 Tahun}

Emosi merupakan kegiatan pada diri seseorang yang disertai warna efektif baik pada tingkat lemah maupun tingkat yang luas (Yusuf, 2007). Perkembangan emosial anak tergantung pada kecerdasan emosionalnya. Makin tinggi kecerdasan emosionalnya, makin baik pula tingkat perkembangannya. Kecerdasan emosional dikategorikan atas lima wilayah, yaitu mengenali emosi diri, mengelola suasana hati, memotivasi diri sendiri, mengenali emosi orang lain, dan membina hubungan (Goteman, 1997).

Kematangan emosional anak sesuai dengan tahap perkembangannya sangat penting untuk dilatih agar dampaknya dapat dirasakan oleh mereka dimasa yang akan datang. Orang tua mempunyai peran utama dalam pengembangan kematangan emosional anak disamping pengaruh faktor lain, karenanya sebagai orang tua hendaknya lebih banyak menempa diri dengan pengetahuan yang memadai tentang perkembangan anak agar mereka dapat memberikan bimbingan kepada anak-anaknya dengan baik. Bermain merupakan kebutuhan anak dalam menjalankan kehidupannya. 
Seiring dengan meningkatnya kemampuan kognitif (di mana pada masa ini anak berada pada akhir dari tahap pra-operasional), anak usia 5-6 tahun mulai mengembangkan pengertian yang lebih dalam terhadap emosi orang lain. Melalui pengalaman yang terjadi secara berulang-ulang, anak dapat mengembangkan konsep sebab-akibat dari emosi yang ia tampilkan. Misalnya, ia dapat mengetahui apa yang terjadi jika ia marah. Anak pada usia dini juga mulai membuat prediksi mengenai tampilan emosi orang lain (Aliah B. Purwakania Hasan, 2006). Hal itu dapat mempengaruhi kemampuannya dalam memperbaiki diri saat berperilaku negative agar ia bisa diterima dengan baik oleh orang lain.

Dengan demikian, pada usia ini penyesuaian diri yang dilakukan oleh anak menjadi lebih matang lagi. Dibandingkan dengan usia-usia sebelumnya, anak lebih percaya diri, punya banyak teman, bisa bercakap-cakap dengan orang dewasa secara nyaman dan dipenuhi oleh perasaan semangat serta antusias saat berhubungan dengan orang lain. Kematangan dalam penyesuaian tersebut menjadikan anak mampu mengatur dirinya sendiri, seperti mampu membersihkan diri di kamar mandi, merapikan pakaiannya sendiri, makan sendiri, mengenakan dan melepaskan pakaian sendiri dan laiinya (Ilman Saputra Dan Alzena Masykouri, 2011).

Ada empat komponen yang harus ditumbuh kembangkan anak pada usia 5-6 tahun agar mereka memiliki kecerdasan emosional. Kelima komponen tersebut antara lain (Novan Ardy Wiyani, 2012):

a. Kemampuan mengenali emosi diri

Kemampuan mengenali emosi diri adalah kesadaran diri dalam mengenali perasaan-perasaannya sewaktu itu terjadi dari waktu ke waktu dalam kehidupannya. Kesadaran diri tersebut pada dasarnya merupakan kemampuan untuk mengenal dan memilah-milah perasaan, memahami hal-hal yang sedang dirasakan, mengapa hal itu dirasakan, dan mengetahui penyebab munculnya perasaan tersebut.

b. Kemampuan mengatur emosi

Kemampuan mengatur emosi diri merupakan kemampuan untuk menangani perasaan agar perasaan dapat terungkap dengan 
pas, kemampuan untuk menghiur diri sendiri, melepaskan kecemasan kemurungan, atau ketersinggungan dan beragai akibat yang muncul dari berbagai emosi yang negatif.

c. Kemampuan mengenali emosi orang lain

Kemampuan mengenali emosi orang lain disebut dengan empati, yaitu kemampuan memahami perasaan orang lain serta mengkomunikasikan pemahaman tersebut kepada orang yang bersangkutan. Kemampuan ini dibangun atas dasar kesadaran diri sendiri, yaitu bahwa oranglain juga memiliki kepentingan seperti halnya diri sendiri,sadar bahwa lingkungan yang membentuk individu itu berbeda-beda dan menyadari bahwa tidak ada manusia yang sama, serta perbedaan itu bukan sesuatu yang harus disikapi dengan perlawanan. Semakin seorang indvidu terbuka dengan dirinya sendiri, semakin ia mampu mengenali dan mengikuti emosinya, dan semakin mudah pula ia mengenali emosi orang lain.

d. Kemampuan mengelola emosi orang lain

Sementara itu, Daniel Goleman dalam Novan Ardy Wiyani mengungkapkan bahwa ada tujuh unsur utama pada kecerdasan emososinal anak usia 5-6 tahun untuk masuk ke kelompok bermain (KB) ataupun taman kanak-kanak (TK).

\section{Konsep Dialek Anak}

Dialek sebagai sistem atau variasi bahasa tercermin dalam pandangan-pandangan para ahli. Weijnen dkk dalam wahya, berpendapat bahwa dialek adalah sistem kebahasaan yang dipergunakan oleh satu masyarakat untuk membedakannya dari masyarakat lain yang bertetangga yang mempergunakan sistem yang berlainan walaupun erat hubungannya (Wahya, 2010).

Richards dkk dalam Wahya membatasi dialek sebagai variasi bahasa yang digunakan disebagian Negeri (dialek regional), atau oleh penduduk yang memiliki kelas sosial tertentu (dialek sosial atau sosiolek), yang berbeda dalam beberapa kata, tata bahasa, dan/atau pelafalan dari bentuk lain pada bahasa yang sama (Wahya, 2010).

Dari beberapa pandangan di atas, dapat disimpulkan bahwa dialek merupakan sistem atau variasi bahasa. Variasi ini bisa berwujud 
variasi regional atau geografis jika digunakan ditempat tertentu, bisa berwujud variasi sosial (sosiolek) jika digunakan oleh kelompok sosial tertentu, dan bisa berwujud variasi temporal jika digunakan pada waktu tertentu.

Dalam hal variasi atau ragam bahasa ini ada dua pandangan. Pertama, variasi atau ragam bahasa itu dilihat sebagai akibat adanya keragaman sosial penutur bahasa itu. Jadi variasi atau ragam bahasa itu terjadi sebagai akibat dari adanya keragaman sosial dan keragaman fungsi bahasa. Andai kata penutur bahasa itu adalah kelompok yang homogeni, baik etnis, status sosial maupun lapangan pekerjaannya, maka variasi atau keragaman itu tidak akan ada, artinya bahasa itu menjadi seragam. Kedua, variasi atau ragam bahasa itu sudah ada untuk memenuhi fungsinya sebagai alat interaksi dalam kegiatan masyarakat yang beraneka ragam. Kedua pandangan ini dapat saja diterima ataupun ditolak. Yang jelas, variasi atau ragam bahasa itu dapat diklasifikasikan berdasarkan adanya keragaman sosial dan fungsi kegiatan didalam masyarakat social (Abdul Chaer, dkk, 2010).

\section{METODOLOGI PENELITIAN}

Metodologi yang digunakan adalah metode kualitatif. Penelitian kualitatif menghasilkan data deskriptif berupa kata-kata tertulis atau lisan dari orang-orang dan perwujudan perilaku yang dapat diamati (Margono, 2003). Adapun lokasi penelitian dalam tulisan ini adalah di Tk Negeri Pembina kecamatan Belo. Pengumpulan data menggunakan teknik wawancara, observasi, dan dokumentasi pada kepala sekolah, guru-guru yang ada di sekolah (Ahmad Usman, 2008). Keabsahan data dilakukan dengan cara member chek, triangulasi, sebab pada penelitian ini data yang diperoleh akan dikumpulkan dan mengetahui kebenarannya. Sedangkan Tekhnik Analisa Data terdiri atas Tekhnik Induktif, Tekhnik Analisa Deduktif, serta penarikan kesimpulan dan saran-saran (Sugiyono, 2013). 


\section{HASIL TEMUAN}

Strategi Guru dalam Membina Perkembangan Emosi Anak Usia 5-6 Tahun Melalui Dialek yang Baik

1. Keadaan Guru dan peserta didik di TK Negeri Pembina Kecamatan Belo

a. Keadaan Guru

Guru adalah orang yang bertanggung jawab dalam pelaksanaan proses belajar mengajar, artinya guru diharapkan untuk bisa mengarahkan kegiatan siswa agar tercapai keberhasilan dalam belajar seperti yang telah dicanangkan sebelumnya. Guru PNS yang ada di TK Negeri Pembina Kecamatan Belo berjumlah 2 Orang orang, Sedangkan untuk guru non PNS berjumlah 3 orang dengan kualifikasi Pendidikan S1diantaranya berkualifikasi pendidikan SMA/sederajat 1 orang.

TABEL.1

Daftar nama guru TK Negeri Pembina Kecamatan Belo Kabupaten Bima tahun 2018/2019

\begin{tabular}{|c|l|c|c|}
\hline No. & \multicolumn{1}{|c|}{ Nama guru } & Jabatan & Ket. \\
\hline 1. & $\begin{array}{l}\text { Siti Sumarni, S.Pd } \\
\text { Nip: 196212311987032182 }\end{array}$ & Kepala Sekolah & \\
\hline 2. & $\begin{array}{l}\text { Eka kurniawati, S.Pd } \\
\text { NIP: } 198305202010012045\end{array}$ & Guru PNS & \\
\hline 3. & Rahmah,S.Pd & Guru non PNS & \\
\hline 4. & Hadijah,S.Pd & Guru non PNS & \\
\hline 5. & Eka Supriati & Guru non PNS & \\
\hline
\end{tabular}

Sumber : Data TK Negeri Pembina Kecamatan Belo (Dokumentasi, 2019)

b. Keadaan siswa

Dalam proses belajar mengajar siswa menduduki peranan yang penting karena dalam proses belajar mengajar kehadiran siswa mutlak diperlukan. Adapun keadaan siswa/siswi TK Negeri 
Pembina Kecamatan Belo tahun pelajaran 2018/2019 secara keseluruhan berjumlah 45 orang siswa dengan jumlah rincian kelompok A sebanyak 15 orang, kelompok B sebanyak 15 orang siswa dan kelompok B1 sebanyak 15 orang siswa (Observasi, 2019). Adapun mengenai keadaan siswa di kelompok B1 TK Negeri Pembina kecamatan belo adalah sebagai berikut :

TABEL. 2

Daftar Nama Peserta Didik TK Negeri Pembina Kecamtan Belo Kelompok : B1

Usia : 5-6 Tahun

\begin{tabular}{|c|l|c|}
\hline NO & \multicolumn{1}{|c|}{ NAMA SISWA } & $\begin{array}{c}\text { JENIS } \\
\text { KELAMIN }\end{array}$ \\
\hline 1 & Alfhian Rahman & L \\
\hline 2 & Alfyah Amaliah Putri & P \\
\hline 3 & Anugra Farija & L \\
\hline 4 & Arif Ferdiansyah & L \\
\hline 5 & Fera Aprilia & P \\
\hline 6 & Fikri Rahman & L \\
\hline 7 & Filzatun Mullisa & P \\
\hline 8 & Hafidzah Sab'ah & P \\
\hline 9 & Nizam Hidayatullah & L \\
\hline 10 & Nur Indah Ramadhani & P \\
\hline 11 & Nur Sakinatun Nadya & P \\
\hline 12 & Nurbaiti Rahmi & P \\
\hline 13 & Nurul Fatiya & P \\
\hline 14 & Sahrul Ramadoan & P \\
\hline 15 & Syahrini Putri & \\
\hline
\end{tabular}

Sumber: Data TK Negeri Pembina Kecamatan Belo (Dokumentasi, 2019)

\section{Pendekatan Secara Emosional}

Emosi mempunyai peranan yang sangat penting dalam kehidupan manusia. Dalam kehidupan sehari-hari, manusia selalu di tuntut untuk mengelola emosinya ketika berkomunikasi dan berinteraksi dengan manusia lainnya. Begitu halnya dengan emosi anak-anak juga memainkan peran yang sangat penting bagi 
kehidupan mereka. Anak-anak mempunyai karakteristik yang berbeda dengan orang dewasa, begitupun dengan perkembangan emosinya yang dikarenakan pengaruh faktor pematangan dan faktor belajar.

Adanya perbedaan latar belakang dialek, sikap, perilaku, serta budaya dari masing-masing anak, peran seorang guru atau pendidik harus cerdas memahami emosi setiap anak.

"Kita sebagai guru harus bisa melakukan pendekatan emosional pada anak yaitu memahami keinginan dan kemauan anak karena tidak semua anak datang dengan latar belakang yang sama, ada anak yang dari desa yang berbeda, logat, dialek dan latar belakang keluarga yang berbeda sehingga saya sebagai guru harus pandai melihat perbedaan itu dan memahami sehingga anak bisa menerima lingkungan baru di sekolah dengan orang yang berbeda dan keluarga yang baru. Kami sebagai guru harus mampu menyatukan perbedaan peserta didik, seperti co toh ada anak yang berasal dari desa renda mereka terlihat kuat dari dialeknya akan mempengaruhi anak yang berasal dari Desa Cenggu Runggu dan Roka. Anak-anak yang berasal dari desa tersebut cenderung lebih takut Karena mendengar dialek dari anak lainnya. Tapi gal itu tidak berlangsung lama yaitu hanya dlam waktu yang singkat saja" (Siti Sumarni, 2019).

Berdasarkan penjelasan responden diatas, maka dapat disimpulkan bahwa dalam memahami emosi anak seorang guru harus melakukan pendekatan dan cerdas memahami emosi anak, sehingga anak-anak tidak merasa diperlakukan tidak adil orang gurunya selain itu tidak terjadi perbedaan mencolok pada anak walaupun mereka berasal dari latar belakang yang berbeda.

\section{Menyediakan Lingkungan Bermain dan Permainan Bagi Anak}

Semboyan di Taman Kanak-Kanak adalah belajar seraya bermain, dan bermain seraya belajar. Eka Supriati menyebutkan, bahwa anak-anak sangat membutuhkan lingkungan bermain sehingga anak merasa senang, selain itu, permainan juga untuk membantu mengenal dan membina emosi anak. Dengan permainan guru bisa melakukan pembiasaan dan penanaman nilai moral kepada anak. Lewat bermain anak-anak ikut bersosialisasi dengan lingkungan dan teman sebayanya. Sehingga perbedaan dari segi 
dialek anak dapat di atasi, selain itu pemberian penguatan nilai-nilai sosial dan emosi juga dapat dilakukan di dalam kelas maupun di luar kelas lewat lingkungan dan permainan yang menyenangkan bagi anak" (Eka Supriati, 2019).

Dengan adanya permainan membantu pengembangan emosi anak karena dengan Bermain memilki sarana tersendiri bagi anak. Kegiatan bermain dapat menjadi sarana sosialisasi diri anak dengan teman sebayanya dan juga sebagai sarana agi anak untuk membawanya leih dekat dengan alamnya. Permainanan juga akan meningkatkan kompetensi social dan emosi anak, membantu anak mengenali diri sendiri untuk membentuk desain kehidupan yang lebih baik. Selain itu permainan juga membantu anak menguasai konflik dan trauma sosial dan emosinya.

\section{Pembiasaan dan Keteladanan}

Salah satu kompetensi yang harus dimiliki oleh guru adalah kompetensi kepribadian. Hal ini dapat mempermudah guru dalam mentransformasikan nilai-nilai dalam proses pembelajaran. Untuk mengembangkan perkembangan emosi anak, maka proses pembiasaan dan keteladanan merupakan cara konkrit yang dilakukan oleh guru di TK Negeri Pembina Kecamatan Belo sebagaimana dijelaskan oleh responden dibawah ini

"Pembiasaan kita berikan diluar ruangan. Seperti untuk menanamkan nilai akhlak, kesopanan, itu sudah tercakup kedalam sikap spiritual anak, untuk penggunaan metodenya kita bisa menggunakan metode demonstrasi, metode bercerita, tanya jawab juga bias. Kita memberikan contoh/teladan dan menjelaskan kepada anak, karena dunia taman kanak-kanak itu, anak menjadikan guru sebagai idola, guru menjadi model anak untuk belajar" (Siti Sumarni, 2019).

Dari penjelasan tersebut, maka dapat dipahami bahwa Anak usia 5-6 tahun sangat sensitif terhadap rangsangan dari luar, maka perilaku dan sepak terjang pendidik maupun orangtua di rumah sangat berpengaruh terhadap anak, cara berbicara, berperilaku, dan bergaul menjadi cermin bagi anak. Di sinilah perlunya keteladanan 
sempurna kepada anak-anak dalam bertutur sapa, berperilaku dan bergaul.

\section{Perlunya Komunikasi Orang Tua dan Guru}

Dalam membina emosi anak melalui dialek yang baik bukan seorang guru saja yang akan membina anak, tetapi sebenarnya harus ada kerja sama yang baik antara seorang guru dengan orangtua. Ibu Siti Hadijah mengemukakan bahwa:

“orangtua adalah lingkungan sosial yang pertama kali di kenal oleh anak sebelum masuk di sekolah, tetapi banyak orangtua yang tidak sadar terhadap perkembangan anaknya. Orangtua seharusnya tidak boleh lengah dengan perkembangan anaknya walaupun dengan hal yang kecil. Tetapi kalo kita lihat orangtua siswa di sini mereka rata-rata berasal dari orangtua yang sangat sibuk, seperti PNS, pekerja kantoran, petani dan lain-lainnya. Contohnya dari anak yang orangtuanya berprofesi sebagai petani malahan banyak yang menitipkan anaknya kepada kakak juga neneknya karena mereka harus pergi menanam bawang di sumbawa. Ini sangat tidak bagus untuk perkembangan anak usia dini, mereka masih membutuhkan perhatian dan kasih sayang dari orangtuanya tapi mau bagaimana lagvi sudah tuntutan hidup juga" (Siti Hadijah, 2019).

Pada jenjang pendidikan taman kanak-kanak, keterbatasan orangtua dalam mendidik anak bisa ditutupi oleh praktik pendidikan yang dilakukan oleh guru di sekolah. Namun, ini bukan berarti pelimpahan tanggung jawab dalam mendidik anak kepada guru di sekolah. Tanggunga jawab sepenuhnya dalam mendidik anak tetap ada pada orangtua, guru sifanya hanya membantu saja, membantu mendidik anak selama beberapa jam ketika anak berada di sekolah. Sehingga dalam mendidik anak, orangtua tidak harus menyerahkan tanggung jawabnya ke guru di sekolah. Justru yang harus dilakukan adalah orangtua harus melibatkan diri dalam mendidik anaknya.

\section{Menerapkan Aturan dan Tata Tertib Tertentu di Sekolah}

Seperti yang kita ketahui pada umumnya bahwa peraturan berguna untuk membatasi manusia untuk melakukan hal yang tidak berdasarkan kesusilaan. Maka dari itu peraturan dibuat untuk dilaksanakan dan ditegakkan. Dengan dibuatnya tata tertib maka terbentuklah pondasi sekolah. Tata tertib dibuat bertujuan untuk 
membentuk karakteristik didikan yang disiplin dan bertanggung jawab agar berlangsungnya proses belajar mengajar yang baik dan bisa melatih serta meningkatkan kebersamaan antar para peserta didik sebagai pelajar di lingkungan sekolah tersebut. Ibu Sumarni mengungkapkan bahwa:

"Lewat Penerapan peraturan dan tata tertib di sekolah akan melatih kedisipilanan seorang anak dalam bertindak maupun bertutur kata. contonya dalam hal menanamkan sikap sabar pada anak, kami bisa melatih dan melihatnya ketika anak mengantri melakukan sesuatu, seperti mengantri untuk masuk kelas, mengantri menggunakan ayunan karena di sini ayunannya ada dua saja, jadi kita bisa melihat di situ apakah anak bisa bersabar dalam berbagi ayunan dan menunggu giliran sehingga kebersamaan dari peserta didik tercipta dengan baik." (Siti Sumarni, 2019).

Sejalan dengan pendapat ibu sumarni diatas, itu ibu Siti Hadijah juga mengungkapkan bahwa, Penerapan peraturan dan tata tertib di sekolah dibuat agar anak terbiasa dengan peraturan dan mengikuti aturan di sekolah tanpa harus didikte atau di suruh-suruh lagi. Peraturan juga akan melatih anak sehingga terbawa sampai dia dewasa nanti. Selain itu penerapan peraturan dan tata tertib di sekolah juga agar melatih kedisiplinan anak sejak dini. Hal ini sangat peting karena di TK adalah wadah awal untuk anak-anak bersosialisasi dengan teman sebaya maupun jenjang pendidikan berikutnya yaitu SD.” (Siti Hadijah, 2019). Jadi, peneliti dapat menyimpulkan bahwa Penerapan peraturan bukan untuk mengekang anak untuk melakukan sesuatu apalagi membatasi anak, akan tetapi lewat ini anak akan melatih diri sehingga anak terbiasa dengan peraturan sejak dini

\section{SIMPULAN}

Berdasarkan data yang diperoleh peneliti baik melalui Observasi, Dokumentasi dan Wawancara di atas, maka peneliti dapat menarik kesimpulan, bahwa Strategi guru dalam membina perkembangan emosi anak usia 5-6 tahun melalui dialek yang baik di TK Negeri Pembina Kecamatan Belo diperoleh dan analisis serta pembahasan yang telah dilakukan, dapat diambil kesimpulan yaitu guru Melakukan pendekatan 
secara emosional dengan anak, Menyediakan lingkungan bermain dan permainan bagi anak, Keteladanan dan pembiasaan, Menerapkan peraturan dan tata tertib di sekolah, dan Perlunya komunikasi antara orangtua dan guru. Guru diharapkan mengenali dan membina perkembangan emosi anak 5-6 tahun melalui dialek yang baik. Serta lebih memahami karakteristik siswa, tidak membeda-bedakan antara siswa yang satu dengan siswa yang lain. Sehingga proses belajar dapat berjalan dengan lancar, agar tujuan pembelajaran dapat tercapai.

\section{DAFTAR PUSTAKA}

Abdul Majid. 2013. Strategi Pembelajaran, Bandung, PT Remaja Rosdakarya.

Adul Chaer, dkk. 2010. Sosiolinguitik: Perkenalan Awal, Jakarta, PT.Rineka Cipta.

Ahmad Usman. 2008. Mari Belajar Meneilti, Yogyakarta, Genta Press.

Aliah B. Purwakania Hasan. 2006. Psikologi Perkembangan Islam: Menyingkap Rentang Kehidupan Manusia Dari Prakelahiran Hingga Pascakematian, Jakarta, Rajawali Press.

Eka Supriati. 2019. Wawancara Dengan Guru TK Negeri Pembina Kecamatan Belo.

George S. Morrison. 2012. Dasar-Dasar Pendidikan Anak Usia Dini (PAUD), Jakarta, PT Indeks.

Goteman. 1997. Emotional Intelligence, Jakarta, Gramedia Pustaka Utama.

Ilman Saputra Dan Alzena Masykouri. 2011. Membangun Sosial-Emosi Anak Usia Dini Di Usia 4-6 Tahun, Jakarta, Dirjen Paudni.

Maratinis Yamin dkk. 2013. Panduan PAUD Pendidikan Anak Usia Dini, Ciputat, Gaung Persada Pres Group.

Margono. 2003. Metodologi Penelitian, Jakarta, Penerbit Rineka Cipta.

M. Sobry Sutikno. 2013. Belajar Dan Pembelajaran, Upaya Kreatif Dalam Mewujudkan Pembelajaran Yang Berhasil, Lombok, Holistica.

Novan Ardy Wiyani. 2012. Pendidikan Karakter Berbasis Iman Dan Taqwa, Yogyakarta, Teras.

Pupuh Fathurrohman \& M. Sobry Sutikno. 2010. Strategi Belajar Mengajar Melalui Penanaman Konsep Umum Dab Konsep Islami, Bandung, Refika Aditama.

Puput Fathurrohman. 2011. Strategi Belajar Mengajar, Bandung, PT Refika Aditama.

Siti Sumarni. 2019. Wawancara Dengan Kepala Sekolah TK Negeri Pembina Kecamatan Belo.

Siti Hadijah. 2019. Wawancara Dengan Guru TK Negeri Pembina Kecamatan Belo.

Sugiyono. 2013. Metode Penelitian Kuantitatif, Kualitatif dan, R \& D, Bandung, Alfabeta.

Taman Firdaus. 2012. Pembelajaran Aktif: Aspek, Teori Dan Implementasi, Yogyakarta, Elmatera. 
Wahya. 2010. "Mengenal Sekilas Dialek tologi: Kajian Interdisipliner Tentang Variasi Dan Perubahan Bahasa" dimuat dalam Lingua Jurnal Ilmiah Bahasa dan Budaya.

Wina Sanjaya. 2013. Strategi Pembelajaran Berorientasi Standar Proses Pendidikan, Jakarta, Kencana Prenadamedia Group.

Yusuf. 2007. Psikologi Perkembangan Anak dan Remaja, Bandung, PT. Rosda Karya Remaja. 